\title{
Comparison of Perinatal Data of Immigrant Women of Turkish Origin and German Women - Results of a Prospective Study in Berlin
}

\author{
Perinataldaten von türkeistämmigen Migrantinnen und deutschen Frauen \\ im Vergleich - Ergebnisse einer prospektiven Studie in Berlin
}

Authors

Affiliations
M. David ${ }^{1}$, T. Borde ${ }^{2}$, S. Brenne ${ }^{1}$, B. Ramsauer ${ }^{3}$, W. Henrich ${ }^{4}$, J. Breckenkamp ${ }^{5}$, O. Razum ${ }^{5}$

Klinik für Gynäkologie, Charité Campus Virchow-Klinikum, Berlin

Alice Salomon University of Applied Sciences, Berlin

${ }^{3}$ Klinik für Geburtsmedizin, Vivantes Klinikum Neukölln, Berlin

${ }^{4}$ Kliniken für Geburtsmedizin, Charité Campus Virchow-Klinikum und Campus Mitte, Berlin

${ }^{5}$ AG Epidemiologie und International Public Health, Universität Bielefeld, Fakultät für Gesundheitswissenschaften, Bielefeld
Key words

- pregnancy

- obstetrics

- birth

- migration

Schlüsselwörter

- Schwangerschaft

- Geburtshilfe

- Geburt

- Migration

Deutschsprachige Zusatzinformationen online abrufbar unter: www.thieme-connect.de/ ejournals/toc/gebfra

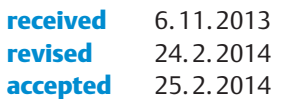

Bibliography

DOI http://dx.doi.org/

10.1055/s-0034-1368489

Geburtsh Frauenheilk 2014; 74 :

441-448 @ Georg Thieme

Verlag KG Stuttgart · New York . ISSN 0016-5751

\section{Correspondence}

Prof. Matthias David

Charité Campus

Virchow-Klinikum

Klinik für Gynäkologie

Augustenburger Platz 1

13353 Berlin

matthias.david@charite.de

\section{Abstract}

\section{$\nabla$}

Aims: The aim of the study was to compare obstetrical process indicators and outcomes for German women with women of Turkish origin residing in Germany. Do women of Turkish origin attend antenatal examinations as frequently as non-immigrant women? Are high-risk pregnancies and anemia more common among immigrant women? Are the rates for epidural analgesia (PDA) and combined spinal-epidural analgesia (CSE) during delivery the same for immigrant women compared to German women? Are there identifiable differences in the mode of delivery and in perinatal outcomes?

Patient Population/Methods: Data were obtained from 3 maternity clinics in Berlin for the period 2011 to 2012. The questionnaires covered socio-demographic factors and information on prenatal care as well as immigration/acculturation. The data obtained from these questionnaires was supplemented by information obtained from the official maternal record of prenatal and natal care (Mutterpass) and perinatal data recorded by the clinic.

Results: The response rate was $89.6 \%$; the data of 1277 women of Turkish origin who had immigrated to Germany or whose family had immigrated and of 2991 non-immigrant women in Germany were included in the study. Regression analysis showed no statistically significant difference in the number of antenatal examinations between immigrant and non-immigrant women. Women of Turkish origin born in Germany had a significantly higher risk of postpartum anemia. PDA/CSE rate, arterial umbilical cord $\mathrm{pH}$ and 5minute Apgar scores did not differ. The incidence of cesarean sections (elective and secondary) was significantly lower in the population of immigrant women of Turkish origin.

Conclusion: Outcomes for most perinatal parameters were comparable for immigrant and non-

\section{Zusammenfassung \\ $\nabla$}

Fragestellungen: Geburtshilfliche Prozess- und Ergebnisindikatoren sollen zwischen deutschen und türkeistämmigen Frauen verglichen werden. Unterscheidet sich die Inanspruchnahme von Schwangerenvorsorgeuntersuchungen bei türkeistämmigen Frauen und Nichtmigrantinnen? Sind Risikoschwangerschaften und Anämien bei Migrantinnen häufiger? Ist die PDA/CSE-Frequenz bei Frauen mit Migrationshintergund sub partu gleich hoch? Lassen sich Unterschiede beim Entbindungsmodus und beim perinatalen Outcome nachweisen?

Patientinnenkollektiv/Methodik: Datenerhebung an 3 Berliner Geburtskliniken 2011/2012 unmittelbar in der Kreißsaalaufnahme über 12 Monate anhand standardisierter Interviews (Fragebogenset) in deutscher oder türkischer Sprache: Fragen zu soziodemografischen und Versorgungsaspekten sowie ggf. Migration/Akkulturation; Ergänzung durch Mutterpassangaben und Klinik-Perinataldaten.

Ergebnisse: Die Rücklaufquote betrug 89,6\%; die Daten von 1277 Frauen mit Migrationshintergrund aus der Türkei und 2991 Frauen ohne Migrationshintergrund konnten verglichen werden. Eine Regressionsanalyse zeigte keinen statistisch signifikanten Unterschied bei der Zahl der Untersuchungen in der Schwangerschaft zwischen den Frauen mit und ohne Migrationshintergrund. In Deutschland geborene Frauen mit Migrationshintergrund aus der Türkei wiesen ein signifikant größeres Risiko für eine postpartale Anämie auf. PDA/CSE-Rate, arterieller-Nabelschnur-pH- und 5-min-Apgar-Werte zeigten keinen Unterschied. Im Gesamtkollektiv der türkeistämmigen Migrantinnen war die Sectio-Häufigkeit (primär/sekundär) signifikant niedriger.

Schlussfolgerungen: Es fanden sich für die meisten perinatalen Parameter vergleichbar gute Resultate bei den Frauen mit und ohne Migrations- 
immigrant women. These results indicate that the achieved standards of antenatal care and medical care during pregnancy are similar for Turkish immigrant women compared to non-immigrant women in maternity clinics in Berlin. The higher rates of anemia among immigrant women should be targeted by preventive measures.

\section{Introduction}

$\nabla$

In the USA, Great Britain, the Netherlands and Scandinavia, obstetrical outcomes have been found to differ between immigrant and non-immigrant women (cf. [1-4]). Unfavorable socio-economic circumstances associated with immigration, a lack of antenatal and perinatal care, difficulties in communication, cultural factors and even insufficiently understood biological factors affecting immigrant women can lead to significantly higher rates of preterm births, increased perinatal mortality rates and higher cesarean section rates. This raises the question whether similar differences in perinatal health and healthcare can also be observed in Germany.

Around 15 million people out of the current population of 80.2 million persons living in the Federal Republic of Germany are first, second, or third-generation immigrants; this corresponds to almost $19 \%$ of the total population; in Berlin this amounts to $23.9 \%$ of the resident population [5]. The first articles on "babies born to foreign women" in Germany were published at the end of the 1960s, and the potential negative impact of a lack of German language skills and limited means of communication on antenatal care and obstetrical outcomes was discussed [6,7].

Only a few studies have been published since then; one important study was a (retrospective) analysis of maternal mortality in Bavaria (for the years 1983 to 2000) which showed a significantly higher mortality rate for immigrant women compared to German women, although the rates began to converge after several years [8]. In 2006 David et al. also published a retrospective study of obstetrical outcomes for immigrant women of mainly Turkish origin, based on perinatal data from Berlin for the years 1993 to 1999 . The study showed that important perinatal quality parameters such as infant and maternal mortality and preterm birth rates have largely converged; however, differences between immigrant and non-immigrant women (rates for cesarean section, epidural anesthesia, and anemia) could indicate persisting differences in the quality of care [9]. The comment in the review article of 2009 by Gissler et al. [11] on the quality of the studies applies both to the above-mentioned studies and to the registerbased analysis of maternal mortality among non-German women published in 1999 by Razum et al. [10]: information on the socio-demographic and immigration background of immigrant women is very limited, as this information is based on population and healthcare registers; this means that detailed information on (immigrant) parents/mothers and their newborn infants is lacking, making it impossible to identify certain causal medical and/ or socio-demographic factors. In particular, it was not possible to verify whether progressive acculturation and integration have resulted in changes and which determinants could have played a role in these changes.

Immigrant women of Turkish origin are the largest group of immigrant women in Germany (besides ethnic German "resettlers") [5]. This group of immigrants already has a long history of immigration to Germany, so that acculturation and integration may have already led to better perinatal outcomes. However, immi- hintergrund. Die Ergebnisse lassen für Migrantinnen aus der Türkei auf einen ähnlichen Standard bei der Inanspruchnahme von Maßnahmen der Schwangerenbetreuung im niedergelassenen Bereich und bei der medizinischen Versorgung in den (Berliner) Geburtskliniken schließen. Die erhöhte Anämierate sollte im Fokus präventiver Maßnahmen stehen.

grants of Turkish origin in Germany are regarded as underprivileged socio-economically and disadvantaged with regard to health and healthcare [12]. This study aimed to examine antenatal and intrapartum process indicators and outcomes for these immigrant groups and compare them to the figures for non-immigrant German women, based on the following 6 questions on antenatal and intrapartum care:

1. Are there differences in attendance rates for antenatal examinations between immigrant and non-immigrant women?

2. Are high-risk pregnancies more common in immigrant women?

3. Is antenatal and postnatal anemia more common in immigrant women?

4. Do immigrant women have similar rates for PDA/CSE administration during delivery compared to non-immigrant women?

5. Are there differences in the mode of delivery?

6. Are perinatal outcomes less favourable for neonates born to immigrant women of Turkish origin?

\section{Methods \\ $\nabla$}

\section{Data collection}

Data collection was done as part of a study financed by the German Research Foundation (Fkz:: DA 1199/2-1) in 3 maternity hospitals in Berlin (Charité/Campus Virchow-Klinikum, Vivantes Klinikum Neukölln, Vivantes Klinikum am Urban) and was based on standardized interviews and validated questionnaires which were available in both German and Turkish. The primary data obtained in this manner was supplemented by information obtained from the Mutterpass, an official maternal record of antenatal and natal care created for every pregnant woman in Germany. This data was then linked to the perinatal data recorded by the respective hospital during delivery, which must be reported to the AQUA Institute as part of quality assurance. The questionnaire consisted of 3 parts: socio-demographic questions (23 items), questions on aspects of care ( 9 items) and, for immigrant women, questions regarding immigration and acculturation $(8+15$ items, respectively).

Determining the immigration status of the women was done in accordance with the recommendation of Schenk et al. (2006) [13]. Using the information provided by the women about the country of birth of their parents, the number of years the women had lived in Germany, their native language, their own assessment of their knowledge and understanding of German, and their residence permit status in Germany, the women of Turkish origin were grouped as follows: 1st generation immigrant = woman born in Turkey; 2nd generation immigrant = both parents born in Turkey; 3rd generation immigrant = native language of the woman is Turkish of Kurdish, the woman herself and both her parents were born in Germany; and women with a so-called binational background (one immigrant-background parent from Turkey and one non-immigrant parent). 
After a preliminary test run, data collection started in January 2011 and was continued for a period of 1 year. Data collection was done by trained multi-lingual study nurses and student researchers working on the project. Data were collected in the labor rooms and maternity wards of the 3 above-listed hospitals using a 2-shift system. The aim was to question the women a few hours before they gave birth.

Inclusion criteria for the study were: all women admitted to one of the three participating maternity hospitals who gave birth to a child (at GW 24/0 and above, with the child showing vital signs) during the study period, who were aged at least 18 years when their child was born, and who had permanent residence in Germany. Women who were underage, tourists who did not reside permanently in Germany, and women who had a termination of pregnancy including miscarriage and stillbirth (death of the child ascertained on admission to hospital and before the onset of labor) were excluded from the study.

\section{Statistical analysis and data protection}

The data of 4598 women were included for analysis in this study. Due to their limited numbers, 3rd generation immigrant women are not listed as a separate group but are included in the group of 2 nd generation immigrant women. For some of the analyses, $1 \mathrm{st}$, 2nd and 3rd generation immigrant women on the one hand, as well as the women with one immigrant parent (binational women) and non-immigrant women on the other hand, were grouped together.

In addition to descriptive analysis, multivariate analysis was done to assess the impact of immigration and acculturation processes on pregnancy and birth. Generalized linear models (Poisson regression models) and binary and multinomial logistic regression analysis were used for multivariate analysis. Persons for whom one or more datasets were missing for independent variables were not included in the respective descriptive and multivariate analyses. This approach explains the differences in the numbers of assessed Mutterpässe. The level of significance was taken as $p<0.05$. All analysis was done using the statistical software SAS 9.2 .

The survey of the women, the compilation and merging of primary and secondary data, and the data assessment complied with German laws on data protection. The Ethics Commission of the Charité University Medicine Berlin approved the study.

\section{Results}

\section{Study population}

A total of 8157 births occurred at the 3 maternity hospitals during the one-year observation period. $9.2 \%$ of women who were approached for the study declined to take part in the study or could not be reached. After applying the inclusion and exclusion criteria, a total of 7100 women were included in the study, which corresponds to a response rate of $89.6 \%$. For the analysis presented here, only immigrant women of Turkish origin $(n=1277)$, non-immigrant women $(\mathrm{n}=2991)$ and so-called binational women were included $(\mathrm{n}=330)$.

The interview with each woman took 15-25 min. Interviews with $6.4 \%$ of $1 \mathrm{st}$ generation immigrant women (of Turkish origin) and with $0.8 \%$ of 2 nd and 3rd generation immigrant women were held in Turkish. Table 1 compares the socio-demographic data for the 4 groups (total number of women: $n=4598$ ).

\section{Antenatal check-up}

In the Mutterpässe available for analysis $(n=3703)$ the numbers of antenatal check-ups ranged between 1 and 35 . The mean figure was 11.2 check-ups (median: 11). Non-immigrant women attended an average of 11.4 antenatal check-ups during pregnancy (median value: 11), binational women attended 11.3 (median: 11), 1st generation immigrant women of Turkish origin attended 10.6 (median: 10) and 2nd/3rd generation immigrant women attended 11.2 antenatal check-ups (median: 11). No statistically significant differences was found between non-immigrant women (reference population) and immigrant women in the expanded Poisson regression model (immigrant status adjusted for additional variables) of the regression analysis for the parameter "number of antenatal examinations attended during pregnancy".

\section{High-risk pregnancies/pregnancy risks}

Based on the data obtained from the Mutterpass, $38.4 \%$ of all women studied $(n=3996)$ had a high-risk pregnancy. High-risk pregnancies were recorded for almost $41 \%$ of non-immigrant women; this figure was only $32 \%$ for 1 st generation immigrant women of Turkish origin, $37 \%$ for 2 nd/3rd generation immigrant women, and $34 \%$ for binational women. The difference between non-immigrant women (reference population) and 1st generation immigrant women of Turkish origin was statistically significant ( $\mathrm{p}<0.001$ ); the difference compared to 2 nd/3rd generation immigrant women $(\mathrm{p}=0.08)$ and to women with binational parents $(\mathrm{p}<0.05)$ was also marked.

There were entries under the heading "pregnancy risks" in the Mutterpass of $76.2 \%$ of all women. Documented pregnancy risks were slightly higher for non-immigrant women (76.4\%) compared to 1 st generation immigrant women of Turkish origin (75.9\%), but levels for non-immigrant women were similar to those of 2nd/3rd generation immigrant women (76.9\%). The most common pregnancy risks listed for the 3996 women included in the study were familial history $(n=915)$ and pregnancy above the age of 35 years $(n=634)$. After adjusting for age, BMI, number of previous births and school-leaving qualifications, 1 st generation immigrant women of Turkish origin had a statistically significantly lower risk of having recorded pregnancy risks compared to non-immigrant women in the generalized linear model (Poisson regression analysis). We also investigated whether immigrants of Turkish origin were less likely to have one or more pregnancy risks compared to non-immigrant women. This was found only to apply to 1st generation immigrant women of Turkish origin (OR: 0.59 ; $95 \% \mathrm{CI}: 0.36-0.97$ ).

\section{Antenatal and postnatal anemia}

Antenatal anemia (defined as a hemoglobin [Hb] value of $<10 \mathrm{~g}$ / dl) was recorded in the Mutterpass of $7.2 \%$ of all investigated women ( $\mathrm{n}=3765$ ); this figure was found to be higher for $1 \mathrm{st}$, 2nd and 3rd generation immigrant women of Turkish origin compared to binational women and non-immigrant women ( Table 2).

While the base model of logistic regression analysis (containing only the variable 'immigrant status') showed a significantly higher chance of antenatal anemia for immigrant women of Turkish origin, only a trend remained in the expanded model which took account of a number of additional co-factors (Table 3 ). The chance of anemia decreases with higher age and increasing BMI, but increases with higher numbers of previous births.

The average $\mathrm{Hb}$ value postpartum was $10.9 \mathrm{~g} / \mathrm{dl}$. The mean $\mathrm{Hb}$ value for $1 \mathrm{st}$ generation immigrant women was $10.9 \mathrm{~g} / \mathrm{dl}$ (median 
Table 1 Comparison of socio-demographic data for the four investigated groups.

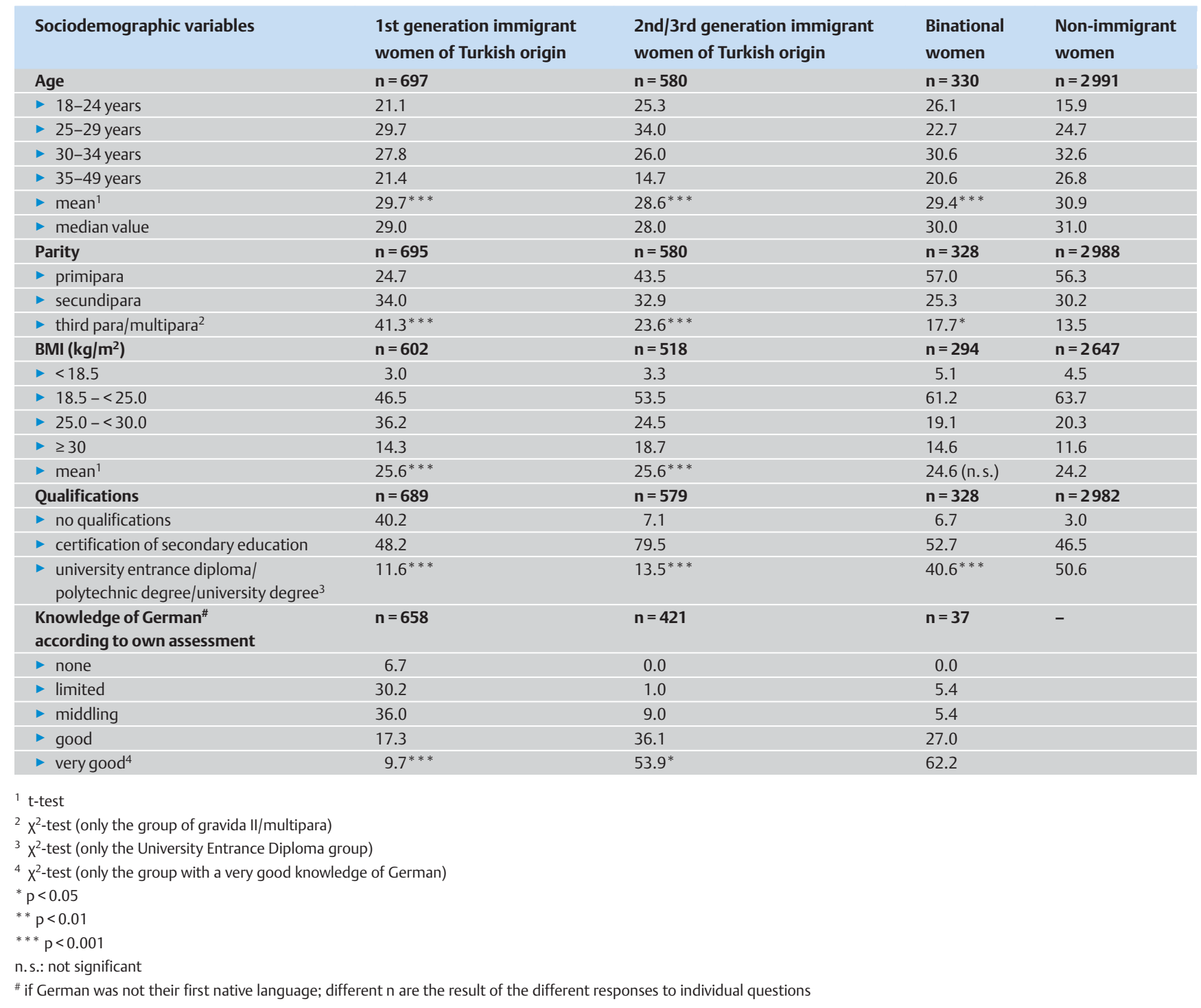

Table 2 Antenatal anemia recorded in the Mutterpass of pregnant women according to the woman's immigrant status $(n=3765)$.

\begin{tabular}{|lrr|} 
& \multicolumn{1}{c}{$\mathbf{n}$} & \multicolumn{1}{c}{$\%$} \\
\hline 1st generation immigrant women of Turkish origin & 64 & 11.4 \\
\hline 2nd/3rd generation immigrant women of Turkish origin & 58 & 11.9 \\
\hline Binational women & 9 & 6.9 \\
\hline Non-immigrant women & 130 & 5.3 \\
\hline Total & 261 & 7.2 \\
\hline
\end{tabular}

$10.9 \mathrm{~g} / \mathrm{dl}$ ); the mean value was $10.6 \mathrm{~g} / \mathrm{dl}$ (median $10.8 \mathrm{~g} / \mathrm{dl}$ ) for 2nd/3rd generation immigrant women, $10.8 \mathrm{~g} / \mathrm{dl}$ (median 10.7) for binational women, and $11.0 \mathrm{~g} / \mathrm{dl}$ (median 11.1) for non-immigrant women. Postpartum anemia with $\mathrm{Hb}$ values below $10 \mathrm{~g} / \mathrm{dl}$ was recorded in $26.7 \%(\mathrm{p}<0.05)$ of 2 nd/3rd generation immigrant women compared to $20 \%$ of non-immigrant women and $21.9 \%(p=0.4292)$ of 1 st generation immigrant women (respective reference: non-immigrant women). An expanded logistic regression analysis model confirmed that 2 nd/3rd generation immigrant women had a significantly higher risk of postpartum anemia. The strongest association was found, as expected, between low $\mathrm{Hb}$ value and increased postpartum bleeding of $>1000 \mathrm{ml}$. Even when the rare incidences of significant blood loss ( $n=43$ in our studied population) were not included in the analysis, immigrant women of Turkish origin, particularly 2nd/3rd generation immigrant women, had significantly lower $\mathrm{Hb}$ values compared to non-immigrant women.

\section{Mode of delivery}

- Table 4 shows the incidence of surgical delivery for the different patient groups (total patient population $n=4595$ ) as well as the incidence of episiotomies and 3rd and 4th grade perineal tears during delivery. There was a significantly higher proportion of higher grade perineal tears in the group of 2 nd/3rd generation immigrant women compared to the other study groups.

Multifactorial logistic regression analysis showed that, after adjustment, there were no significant differences between the four study groups with regard to surgical vaginal deliveries, while Csection rates were significantly lower in the group of immigrant women (OR: 0.71; p < 0.001). 
Table 3 Chance of antenatal anemia (based on Mutterpass records), logistic regression ( $n=3765)$ (bold: $p$-value $<0.05)$.

\begin{tabular}{|c|c|c|c|}
\hline$n=3765$ & OR & $95 \% \mathrm{Cl}$ & p-value \\
\hline Non-immigrant women & 1.00 & & \\
\hline 1st generation immigrant women & 1.37 & $0.66-2.86$ & 0.4037 \\
\hline 2nd generation immigrant women & 1.59 & $0.81-3.11$ & 0.1797 \\
\hline Binational women & 1.16 & $0.69-1.95$ & 0.5881 \\
\hline \multicolumn{4}{|l|}{ Age } \\
\hline - $18-24$ years & 1.00 & & \\
\hline - 25-29 years & 0.79 & $0.56-1.13$ & 0.2014 \\
\hline - 30-34 years & 0.68 & $0.46-0.99$ & 0.0436 \\
\hline - 35-49 years & 0.71 & $0.46-1.08$ & 0.1058 \\
\hline \multicolumn{4}{|l|}{ Parity } \\
\hline - nullipara & 1.00 & & \\
\hline - primipara/secundipara & 1.04 & $0.79-1.38$ & 0.7794 \\
\hline - multipara & 1.64 & $0.99-2.71$ & 0.0540 \\
\hline \multicolumn{4}{|l|}{ BMI $\left(\mathrm{kg} / \mathrm{m}^{2}\right)$} \\
\hline$-<25$ & 1.00 & & \\
\hline - $25-<30$ & 0.78 & $0.57-1.06$ & 0.1120 \\
\hline > $30+$ & 0.58 & $0.38-0.90$ & 0.0134 \\
\hline \multicolumn{4}{|l|}{ Qualifications } \\
\hline $\begin{array}{l}\text { university entrance diploma/ } \\
\text { polytechnic degree/ } \\
\text { university degree }\end{array}$ & 1.00 & & \\
\hline $\begin{array}{l}\text { certificate of secondary } \\
\text { education/vocational training }\end{array}$ & 1.23 & $0.88-1.70$ & 0.2228 \\
\hline - no qualifications/primary school & 1.32 & $0.80-2.19$ & 0.2764 \\
\hline \multicolumn{4}{|l|}{ Native language } \\
\hline - German & 1.00 & & \\
\hline > other & 1.44 & $0.74-2.80$ & 0.2873 \\
\hline - bilingual & 1.47 & $0.64-3.39$ & 0.3628 \\
\hline \multicolumn{4}{|l|}{ Pregnancies in rapid succession } \\
\hline - no & 1.00 & & \\
\hline > yes & 0.78 & $0.40-1.52$ & 0.4671 \\
\hline
\end{tabular}

Compared to non-immigrant women, immigrant women of Turkish origin had an overall lower risk of secondary C-section (OR: 0.69; 95\% CI: 0.54-0.87). Moreover, immigrant women had significantly lower elective C-section rates (OR: 0.73; 95\% CI: $0.55-$ 0.96). A poorer understanding of German was also associated with a lower rate of elective C-section (OR: 0.47; 95\% CI: $0.23-$ 0.96). However, after adjustment, difference in the risk of episiotomy and of higher grade perineal tears between immigrant and non-immigrant women was not statistically significant (OR: $1.15 ; \mathrm{p}=0.33$ and $\mathrm{OR}: 0.79 ; \mathrm{p}=0.46$ respectively).

\section{Incidence of PDA/CSE}

The recorded rates for epidural anesthesia (PDA) and combined spinal-epidural analgesia (CSE) during delivery differed according to the study group and the mode of delivery. In the group of vaginal deliveries, $44.4 \%$ of non-immigrant women and $28.2 \%$ $(p<0.001)$ of immigrant women of Turkish origin had a PDA/ CSE; in the group who underwent secondary C-section $84.4 \%$ of non-immigrant women and $75.4 \%$ of immigrant women had this form of analgesia $(\mathrm{p}<0.01)$. Multivariate analysis found no significant difference in the chance of PDA/CSE between immigrant women of Turkish origin and non-immigrant women. However, a limited understanding of German by immigrant women was associated with a significantly lower chance of PDA/CSE (OR: 0.67; 95\% CI: 0.48-0.95).

\section{Perinatal outcome}

- Table 5 shows the rates for normal and critical $\mathrm{pH}$ values for arterial umbilical cord blood and for 5-minute Apgar scores. Additionally (not shown in $\odot$ Table 5), more than $93 \%$ of neonates (in multiple births, only the first child was included) had a 1-minute Apgar score of between 7 and 10 points. Only $0.4 \%$ of all neonates had a 10-minute Apgar score of less than 7 after delivery. For logistic regression analysis, neonates who had a $\mathrm{pH}$ value for arterial umbilical cord blood of $\leq 7.10$ (dependent variable) were grouped together. 1st generation immigrant women of Turkish origin had a lower chance of $\mathrm{pH}$ values of arterial umbilical cord blood of 7.10 or less, compared to non-immigrant women. However, this association did not reach statistical significance ( $p>0.06)$. As expected, there was a strong association between adverse arterial umbilical cord $\mathrm{pH}$ values and low 5-minute Apgar scores ( $\bullet$ Table 6 ).

\section{Discussion}

Two recent review articles have examined the most important associations between perinatal outcomes and immigration in European countries. After a detailed analysis of evidence-based studies for the period 1970-2004, the review by Bollini et al., published in 2009, came to conclusion that immigrant women are at a disadvantage, at least with regard to perinatal outcomes, and that this disadvantage persists over several generations. These negative impacts were apparently much reduced in countries with comprehensive and wide-ranging integration policies [14]. The study by Gissler et al., also published in 2009, looked at

Table 4 Incidence of surgical deliveries, episiotomies and higher grade perineal tears according to the mother's immigration status (in \%).

\begin{tabular}{|c|c|c|c|c|}
\hline & $\begin{array}{l}\text { 1st generation immigrant } \\
\text { women of Turkish origin }\end{array}$ & $\begin{array}{l}\text { 2nd/3rd generation immigrant } \\
\text { women of Turkish origin }\end{array}$ & $\begin{array}{l}\text { Binational } \\
\text { women }\end{array}$ & $\begin{array}{l}\text { Non-immigrant } \\
\text { women }\end{array}$ \\
\hline Total cesarean section rate & $22.0^{* * *}$ & $31.7^{* * *}$ & 38.8 (n.s.) & 39.3 \\
\hline - elective C-section & 10.5 & 12.2 & 13.6 & 15.4 \\
\hline - secondary C-section & 11.5 & 19.5 & 25.2 & 23.9 \\
\hline Vacuum extraction & 8.9 (n.s.) & 8.6 (n.s.) & 10.3 (n.s.) & 9.5 \\
\hline Forceps delivery & 0.0 & 0.2 & 0.0 & 0.1 \\
\hline Episiotomy & $8.1^{*}$ & 10.2 (n.s.) & 9.8 (n.s.) & 11.4 \\
\hline 3rd/4th grade perineal tear & 0.7 (n.s.) & $2.4^{*}$ & 0.6 (n.s.) & 1.1 \\
\hline
\end{tabular}

n. s. = not significant

* $\mathrm{p}<0.05$

$* * * \mathrm{p}<0.001$ 
Table $5 \mathrm{pH}$ values for arterial umbilical cord blood and Apgar scores for neonates at 5 minutes after delivery according to the mother's immigration status (in \%) $(n=4552)$.

\begin{tabular}{|c|c|c|c|c|}
\hline & $\begin{array}{l}\text { 1st generation immigrant } \\
\text { women of Turkish origin }\end{array}$ & $\begin{array}{l}\text { 2nd/3rd generation immigrant } \\
\text { women of Turkish origin }\end{array}$ & $\begin{array}{l}\text { Binational } \\
\text { women }\end{array}$ & $\begin{array}{l}\text { Non-immigrant } \\
\text { women }\end{array}$ \\
\hline \multicolumn{5}{|l|}{$\mathrm{pH}$ value for arterial umbilical cord blood } \\
\hline normal values: $>7.10^{1}$ & 98.4 (n.s.) & 97.4 (n.s.) & 97.3 (n.s.) & 96.8 \\
\hline - borderline value: $\geq 7.00$ to $\leq 7.10$ & 1.3 & 2.6 & 2.5 & 2.9 \\
\hline - critical range: $<7.00$ & 0.3 & 0.0 & 0.3 & 0.3 \\
\hline \multicolumn{5}{|l|}{$\begin{array}{l}\text { Apgar scores } \\
5 \text { min after delivery }\end{array}$} \\
\hline $0-3$ points & 0.0 & 0.0 & 0.0 & 0.3 \\
\hline - $4-6$ points & 1.5 & 1.9 & 2.1 & 2.3 \\
\hline - 7-10 points ${ }^{2}$ & 98.5 (n.s.) & 98.1 (n.s.) & 97.9 (n.s.) & 97.5 \\
\hline
\end{tabular}

${ }^{1} \mathrm{x}^{2}$-test (only group with normal $\mathrm{pH}$ values)

$x^{2}$-test (only group with $7-10$ points)

Table 6 Chance of $\mathrm{pH}$ values of arterial umbilical cord blood $\leq 7.10$; logistic regression ( $\mathrm{n}=4552$ ) (bold: $\mathrm{p}<0.05)$.

\begin{tabular}{|c|c|c|c|}
\hline & OR & $95 \% \mathrm{Cl}$ & p-value \\
\hline Non-immigrant women & 1.00 & & \\
\hline 1st generation immigrant women & 0.51 & $0.25-1.04$ & 0.0631 \\
\hline $\begin{array}{l}\text { 2nd/3rd generation immigrant } \\
\text { women }\end{array}$ & 0.88 & $0.49-1.56$ & 0.6576 \\
\hline Binational women & 0.88 & $0.44-1.77$ & 0.7199 \\
\hline \multicolumn{4}{|l|}{ Age } \\
\hline - $18-24$ years & 1.00 & & \\
\hline - 25-29 years & 1.71 & $0.95-3.11$ & 0.0757 \\
\hline - 30-34 years & 1.74 & $0.96-3.16$ & 0.0674 \\
\hline - 35-49 years & 0.94 & $0.48-1.88$ & 0.8595 \\
\hline \multicolumn{4}{|l|}{ Apgar score } \\
\hline - $5 \min (7-10)$ & 1.00 & & \\
\hline$>5 \min (0-6)$ & 4.53 & $2.26-9.09$ & $<0.0001$ \\
\hline \multicolumn{4}{|l|}{ Birth weight } \\
\hline$\Rightarrow \geq 2500 \mathrm{~g}$ & 1.00 & & \\
\hline - $<2500 \mathrm{~g}$ & 1.50 & $0.68-3.30$ & 0.3105 \\
\hline \multicolumn{4}{|l|}{ Birth } \\
\hline$>>37 / 0 \mathrm{GW}$ & 1.00 & & \\
\hline D $\leq 37 / 0 \mathrm{GW}$ & 0.60 & $0.27-1.36$ & 0.2207 \\
\hline \multicolumn{4}{|l|}{ Qualifications } \\
\hline $\begin{array}{l}\text { vocational diploma/university } \\
\text { entrance diploma/polytechnic } \\
\text { degree/university degree }\end{array}$ & 1.00 & & \\
\hline $\begin{array}{l}\text { certificate of secondary } \\
\text { education/vocational training }\end{array}$ & 0.80 & $0.54-1.10$ & 0.2753 \\
\hline - no qualifications/primary school & 1.03 & $0.47-2.26$ & 0.9481 \\
\hline \multicolumn{4}{|l|}{ Multiple births } \\
\hline no multiple birth & 1.00 & & \\
\hline - multiple birth & 0.60 & $0.18-2.05$ & 0.4178 \\
\hline
\end{tabular}

all available 42 studies for these years to see whether they could identify an association between increased perinatal mortality and mother's immigrant status. They found that some immigrant populations had equally good, sometimes even better, perinatal health compared to the population of the host country. One explanation for this was the so-called 'healthy migrant effect' (a self-selection of particularly healthy people who immigrated). Other immigrant groups had poorer overall perinatal outcomes; the authors explained this as caused by maternal milieu, health behavior, socio-economic conditions, disparities with regard to access to and utilization of healthcare facilities, and social factors [11].
Investigations in the USA, Australia and Germany in the 1980s established relatively consistently that immigrant women generally attended fewer antenatal examinations during pregnancy [15-17]. Based on an analysis of all singleton pregnancies registered in Finland in the years 1999 to 2001, Malin and Gissler established that there was no significant difference in the number of attended antenatal check-ups between immigrant women and women born in Finland [4]. In 2012, Martinez-Garcia et al. published a hospital-based retrospective analysis on this issue and reported that women from Eastern Europe and from the Maghreb generally attended fewer antenatal check-ups compared to non-immigrant Spanish women [18]. For the federal state of Baden-Württemberg in Germany, Simoes et al. already noted in 2003 after an analysis of perinatal data that the tendency among non-German women to attend fewer antenatal examinations was decreasing compared to the 1970s and 1980s [19]. For Berlin we were unable to find any current differences in the number of antenatal examinations attended during pregnancy between immigrant and non-immigrant groups of women.

An Austrian study by Oberaigner et al. showed that immigrant women of Turkish origin had significantly fewer pregnancy risks compared to immigrant women from other countries and nonimmigrant women born in Austria [20]. We were able to confirm this finding for Berlin for 1st generation immigrant women of Turkish origin. The picture was different for 2nd/3rd generation immigrant women of Turkish origin. It would appear that the results for this group tend to converge with the results for the nonimmigrant population.

Endl and Tatra already reported higher anemia prevalences in pregnant women of Turkish origin in the 1970s [21]. Chan et al. also described this phenomenon in their study, published in 1988 , for groups of immigrants from different countries living in Australia, and Jans et al. reported the same phenomenon in 2009 for non-North European immigrant women living in Amsterdam $[16,22]$. In our study we found that postpartum anemia prevalences were significantly higher for 2nd and 3rd generation immigrant women of Turkish origin compared to non-immigrant women or 1st generation immigrant women. Because of their rare clinical manifestation, hemoglobinopathies and thalassemias cannot serve as an explanation for this discrepancy [23,24]. In contrast to Walsh et al., who reported in their hospital-based study in Dublin that Irish women were more likely to have epidural analgesia during delivery compared to women from Eastern Europe [25], we were unable to detect differences between Ger- 
man women and women of Turkish origin in our Berlin study population. However, we did find a difference compared to women with very limited or no understanding of German. This mirrored the results of the study by Oberaigner et al. for various Austrian maternity hospitals. In their study, published in 2013, they found that the epidural analgesia rates increased when immigrant women had stayed longer in Austria and their German language skills had improved 20]. Problems of language and communication when providing information about the available options for anesthetization during delivery need to be considered as a possible cause of the lower rates for immigrant women.

The significantly higher rate of planned/primary cesarean sections in the German sub-group may also point to a problem in the care system. In 2004, Rizzo et al. used matched pairs analysis to compare Italian women with non-EU immigrant women and also noted a higher rate of primary/elective cesarean sections among Italian women. They ascribed this to the medical staff being less worried about legal claims when dealing with immigrant women, meaning that staff were more likely to encourage vaginal births in low-risk immigrant women. Moreover, differences in socio-cultural ideas about pregnancy and birth between immigrant and non-immigrant women and other traditional notions about birth processes could also play a role [26].

In contrast to our findings, several studies have reported a higher incidence of secondary cesarean sections in immigrant women and ethnic minorities [27-29]. In 2000, Vangen et al. carried out a detailed analysis of 553491 live births recorded in the Norwegian register of births for the period 1986-1995 and found a higher rate of cesarean sections for immigrant women from the Indian subcontinent, from Africa and from Latin America; however the rates for immigrant women of Turkish origin were similar to those of non-immigrant women [30].

In 2012, von Katterfeld et al. published an analysis of cesarean sections in Western Australia for the period 1998-2006; they found that certain groups of African and Asian immigrant women had significantly higher rates of secondary C-sections, while other groups had lower rates of primary/elective C-sections compared to Australian-born women. In addition to medical and obstetric considerations, the authors were of the opinion that sociocultural aspects and attitudes to cesarean sections must also be considered as causative factors. Either obstetricians are less likely to offer elective cesarean sections to immigrant women or immigrant women consciously reject this mode of delivery [31]. In 2010 Rio et al. published an analysis of 215000 singleton births in Spain and found that the general risk for immigrant women to deliver their baby by cesarean section was lower than for native-born Spanish women (RR: 0.83) [32]. In a 2013 perinatal study of several Austrian maternity units, Oberaigner et al. reported that immigrant women of Turkish origin had significantly higher vaginal delivery rates and lower elective C-section rates [20].

In our study, the condition of neonates, as determined immediately after birth based on arterial umbilical cord blood $\mathrm{pH}$ and 5minute Apgar scores, did not show poorer outcomes for the immigrant group; in fact, there were no significant differences in neonatal outcomes between groups. In contrast, the 2011 study of Cacciani et al., which analyzed all births in the Italian region of Lazio, found that Apgar scores were lower for infants born to immigrant women [33]. A recent (2013) study was published by Margioula-Siarkou et al. and consisted of a retrospective analysis of around 7000 births in a hospital in Greece; in this study, the children of the immigrant group had better Apgar scores at 1 and 5 minutes after delivery [34].

Our study has a number of methodological strengths; this includes the large number of cases studied and the very high response rate, particularly from the subgroup of immigrant women of Turkish origin. In contrast to many exclusively register-based studies done in Germany (Razum et al., 2011 [35]), our study included a carefully differentiated examination of immigration status, degree of acculturation and socio-economic status and analyzed the impact of these different factors separately. Differences in how data was entered in the Mutterpass and in obtaining perinatal data could be a methodological weakness. Moreover, the results from a metropolis with a large population of immigrants may not necessarily be transferrable to smaller towns or rural regions with a lower proportion of immigrants in the general population. Despite these critical points, our study currently offers the most valid results.

\section{Conclusion \\ $\nabla$}

For the large group of immigrant women of Turkish origin living in Berlin we found that the results for most perinatal parameters were similar to those for non-immigrant women. In particular, our study showed that rates for attending antenatal examinations and the level of medical obstetric care in maternity hospitals in Berlin were similar for immigrant women and non-immigrant women; these results probably also apply to other large cities and industrial urban agglomerations in Germany. As regards the (limited) differences between immigrant and non-immigrant groups found in this study, the following conclusions must be drawn with respect to the obstetrical care offered to immigrant women of Turkish origin:

1. The overall lower rate of C-section deliveries, particularly the lower rates of elective cesarean sections in the immigrant group, should prompt a search for possible causal and protective factors. The difference may be due to a different approach to giving birth on the part of the mother. The attitudes of healthcare staff and the advice offered by physicians could also play a role.

2. The lower rates for PDA/CSE administration during delivery among immigrant women of Turkish origin with a limited understanding of German must be further investigated as it could be taken as an indication of a difference in the quality of care which has not yet been remedied.

3. The unfavorably high anemia rates postpartum in a subgroup of immigrant women of Turkish origin should lead to increased prophylactic measures and should also prompt physicians to look actively for anemia and its causes in this group of women who have given birth, not merely in connection with obstetrical problems.

\section{Funding \\ $\nabla$}

Partly funded by German Research Foundation (DFG), DA1199/ $2-1$.

\section{Conflict of Interest \\ $\nabla$}

None. 


\section{References}

1 Gould JB, Madan A, Cheng $Q$ et al. Perinatal outcomes in two dissimilar immigrant populations in the United States: a dual epidemiologic paradox. Pediatrics 2003; 111: 676-682

2 Hawkins SS, Lamb K, Cole TJ; Millennium Cohort Study Child Health Group. Influence of moving to the UK on maternal health behaviours: prospective cohort study. BMJ 2008; 336: 1052-1055

3 Troe EJ, Raat H, Jaddoe VW et al. Explaining differences in birthweight between ethnic populations. The Generation R study. BJOG 2007; 114: 1557-1565

4 Malin M, Gissler M. Maternal care and birth outcomes among ethnic minority women in Finland. BMC Public Health 2009; 9: 84

5 Statistisches Bundesamt, Hrsg. Zensus 2011. Bevölkerung Bundesrepublik Deutschland am 9. Mai 2011. Wiesbaden: Statistisches Bundesamt, Hrsg.; 2013

6 Rimbach E. Schwangerschaften und Geburten bei Ausländerinnen. Arch Gynacol 1967; 204: 293-295

7 Sauerwein A. Entbindungen bei Ausländerinnen, zugleich ein Beitrag zur Frequenz und Indikationsstellung der abdominalen Schnittentbindung. Geburtsh Frauenheilk 1969; 29: 728-734

8 Welsch H, Krone HA, Wisser J. Maternal mortality in Bavaria between 1983 and 2000. Am J Obstet Gynecol 2004; 191: 304-308

9 David M, Pachaly J, Vetter K. Perinatal outcome in Berlin (Germany) among immigrants. Arch Gynecol Obstet 2006; 274: 271-278

10 Razum 0, Jahn A, Blettner $M$ et al. Trends in maternal mortality ratio among women of German and non-German nationality in West Germany, 1980-1996. Int J Epidemiol 1999; 28: 919-924

11 Gissler M, Alexander S, MacFarlane A et al. Stillbirths and infant deaths among migrants in industrialized countries. Acta Obstet Gynecol Scand 2009; 88: 134-148

12 Razum O, Zeeb H, Meesmann $U$ et al. Migration und Gesundheit. Schwerpunktbericht der Gesundheitsberichterstattung des Bundes. Berlin: Robert Koch-Institut; 2008

13 Schenk L, Bau AM, Borde T et al. Mindestindikatorensatz zur Erfassung des Migrationsstatus. Empfehlungen für die epidemiologische Praxis. Bundesgesundheitsbl Gesundheitsforsch Gesundheitsschutz 2006; 9: 853-860

14 Bollini P, Pampallona S, Wanner P et al. Pregnancy outcome of migrant women and integration policy: a systematic review of the international literature. Soc Sci Med 2009; 68: 452-461

15 Katusic SK, Colligan RC, Barbaresi WJ et al. Potential influence of migration bias in birth cohort studies. Mayo Clinic Proc 1986; 73: 10531061

16 Chan A, Roder D, Marchaper T. Obstetric profiles of immigrant women from non-English speaking countries in South Australia, 1981-1983. Aus NZ J Obstet Gynaecol 1988; 28: 90-95

17 Oeter K, Collatz J, Hecker H et al. Werden die präventiven Möglichkeiten der Schwangerenvorsorge ausreichend genutzt? Erste Ergebnisse der Perinatalstudie Hannover. Gynäkologe 1979; 12: 164-174

18 Martínez-García E, Olvera-Porcel MC, de Dios Luna-Del Castillo J et al. Inadequate prenatal care and maternal country of birth: a retrospective study of southeast Spain. Eur J Obstet Gynecol Reprod Biol 2012; 165 : 199-204
19 Simoes E, Kunz S, Bosing-Schwenkglenks $M$ et al. Inanspruchnahme der Schwangerenvorsorge - ein Spiegel gesellschaftlicher Entwicklungen und Aspekte der Effizienz. Untersuchung auf der Basis der Perintalerhebung Baden-Württemberg 1998-2001. Geburtsh Frauenheilk 2003; 63: 538-545

20 Oberaigner $W$, Leitner $H$, Oberaigner $K$ et al. Migrants and obstetrics in Austria - applying a new questionnaire shows differences in obstetric care and outcome. Wien Klin Wochenschr 2013; 125: 34-40

21 Endl J, Tatra G. Geburtshilfliche Aspekte bei Gastarbeiterinnen. Wien Klin Wochenschr 1974; 86: 102-105

22 Jans SM, Daemers DO, de Vos $R$ et al. European descent more anaemic than women of Northern European descent? A study into the prevalence of anaemia in pregnant women in Amsterdam. Midwifery 2009; 25: 766-773

23 Dickerhoff R, Kulozik AF, Kohne E. Betreuung von Schwangeren aus Risikoländern mit Sichelzellerkrankungen und Thalassämien. Klinik, Screening und Pränatale Diagnostik. Geburtsh Frauenheilk 1993; 53: 215-220

24 Kohne E. Hemoglobinopathies: clinical manifestations, diagnosis, and treatment. Dtsch Arztebl Int 2011; 108: 532-540

25 Walsh J, Mahony R, Armstrong F et al. Ethnic variation between white European women in labour outcomes in a setting in which the management of labour is standardised - a healthy migrant effect? BJOG 2011; 118: 713-718

26 Rizzo N, Ciardelli V, Gandolfi Colleoni G et al. Delivery and immigration the experience of an Italian hospital. Europ J Obstet Gynecol Reprod Biol 2004; 116: 170-172

27 Braveman P, Egerter S, Edmonston F et al. Racial/ethnic differences in the likelihood of cesarean delivery, California. Am J Public Health 1995; 85: 625-630

28 Diani F, Zanconato G, Foschi F et al. Management of the pregnant immigrant woman in the decade 1992-2001. J Obstet Gynaecol 2003; 23 . 615-617

29 Ibison JM. Ethnicity and mode of delivery in 'low-risk' first-time mothers, East London, 1988-1997. Europ J Obstet Gynecol 2005; 118: 199205

30 Vangen S, Stoltenberg C, Skrondal A et al. Cesarean section among immigrants in Norway. Acta Obstet Gynecol Scand 2000; 79: 553-558

31 von Katterfeld B, Li J, McNamara B et al. Perinatal complications and cesarean delivery among foreign-born and Australian-born women in Western Australia, 1998-2006. Int J Gynecol Obstet 2012; 116: $153-$ 157

32 Río I, Castelló A, Barona C et al. Caesarean section rates in immigrant and native women in Spain: the importance of geographical origin and type of hospital for delivery. Eur J Public Health 2010; 20: 524-529

33 Cacciani L, Asole S, Polo A et al. Perinatal outcomes among immigrant mothers over two periods in a region of central Italy. BMC Public Health 2011; 11: 294

34 Margioula-Siarkou C, Petousis S, Kalogiannidis I et al. Immigrants present improved obstetric and neonatal outcomes compared to native women. A northern Greek population analysis. J Immigr Minor Health 2013; 15: 249-254

35 Razum 0, Reeske A, Spallek J, Hrsg. Gesundheit von Schwangeren und Säuglingen mit Migrationshintergrund. Frankfurt/Main: Peter Lang Verlag; 2011 